\title{
Analisis Pemilihan Wilayah Terkait dengan TPA Regional di TPST Bantargebang Menggunakan Metode Topsis
}

\section{Analysis of Related Area Preference with Regional Sanitary Landfill in Temporary Bantargebang Sanitary Landfill Using Topsis Method}

\author{
DOUGLAS MANURUNG ${ }^{1)}$, HMH. BINTORO ${ }^{2)}$, SETIA HADI') ${ }^{2)}$ ISKANDAR LUBIS ${ }^{2)}$ \\ ${ }^{1)}$ Program Doktor SPS IPB, ${ }^{2)}$ Dosen Pascasarjana IPB, \\ Kampus IPB Darmaga, Bogor 16880 \\ douglasmanurung@yahoo.com,
}

\begin{abstract}
In the year of 2008, Act of The Republic of Indonesia Number 18 Year 2008 regarding Municipal Solid Waste (MSW) Management has been issued. Some of the objectives of this Act are: (1) all of MSW Disposal Sites (TPA) in Indonesia must use sanitary landfill type, and (2) a partnership can be formed between two or more local governments to manage their MSW in a Regional MSW Disposal Site (TPA Regional) together with investor and local community. Somehow these goals are difficult to achieve because of limited budget and complexities in selecting which local governments should do the partnership and what kind of institution they could build to carry all the partnership agreements. Thus, Technique for Order Preference Similarity to Ideal Solution (TOPSIS) was employed for this research to help determine which ones of eight regions in JABODETABEK should become the parts of the partnership so they can deliver their solid waste to TPST Bantargebang, as a Regional Solid Waste Disposal Site (TPA Regional). It concludes that Kota Bekasi is the best alternative to use TPST Bantargebang as TPA Regional with Ci+ value closer to 1. The second and the third best alternatives are Kabupaten Bekasi and Kabupaten Bogor, respectively. Besides, the TPST Bantargebang could be developed to be a regional disposal site through extensification programme up to 25 hectare of additional area, about 30 meter of landfill waste effective height and 3 meter of waste trap height. It is used waste weight to volume ratio of $1,000 \mathrm{~kg}$ per $3 \mathrm{m3}$, compaction factor of 50 percent and natural reduction factor of 30 percent. With that condition, TPST Bantargebang still can receive waste up to 2,422 ton per day in 15 years ahead.
\end{abstract}

Keywords: extensification programme, partnership, regional solid waste disposal site, TOPSIS

\begin{abstract}
ABSTRAK
Implementasi Undang-undang No. 18 tentang Pengelolaan Sampah yang mengatur Tempat Pemrosesan Akhir (TPA) sampah di Indonesia memiliki kesulitan pencapaian karena bketerbatasan anggaran, kesulitan pemilihan lokasi, dan pemilihan institusi penanggung jawab. Dengan menggunakan Technique For Order Preference Similarity To Ideal Solution (TOPSIS), bisa ditentukan wilayah mana saja dari 8 (delapan) kota dan kabupaten di JABODETABEKyang bekerjasama untuk membentuk TPA regional di TPST Bantargebang. Hasil TOPSIS menyimpulkan bahwa Kota Bekasi adalah alternatif terbaik untuk memakai TPST Bantargebang dengan nilai $\mathrm{Ci}^{+}$mendekati 1 . Dua tempat terbaik setelahnya adalah Kabupaten Bekasi, dan Kabupaten Bogor. TPST Bantargebang dapat dikembangkan menjadi sebuah TPA regional dengan perluasan lahan sebesar 25 ha, menaikkan ketinggian landfill menjadi 30 meter, dan ketinggian jaraktrap 3 meter, faktor konversi volume $1000 \mathrm{~kg}$ sampah sama dengan $3 \mathrm{~m}^{3}$, faktor pemadatan 50 persen dan faktor reduksi alami sampah sebsar 30 persen. Dengan kondisi tersebut TPST Bantargebang masih dapat menerima tambahan sampah sebesar 2.422 ton per hari sampai 15 tahun ke depan.
\end{abstract}

Kata kunci: kerjasama, program ekstensifikasi, TOPSIS, TPA Regional. 


\section{PENDAHULUAN}

Pengembangan TPA (Tempat Pemrosesan Akhir) sampah regional, perlu dilakukan sesegera mungkin, sehingga diharapkan pengelolaan sampah di Indonesia dapat dilakukan dengan lebih baik dan tersistem, danpemerintah daerah dapat mengatasi persoalan-persoalan dalam hal mengelola sampahnya.Namun demikian dalam melaksanakan hal tersebut masih terdapat masalah-masalah yang dihadapi oleh pemerintah daerah, seperti keterbatasan anggaran yang tersedia untuk pengelolaan sampah serta ketersediaan lahan yang cukup dan sesuai untuk pengembangan TPA.

Salah satu harapan dari pengembangan TPA sampah regional, antara lain adalah Konsep TPA regional yang tidak terlepas dari konsep kerjasama antardaerah.Dengan diberlakukannya Undang-undang Nomor 22 Tahun 1999 yang diperbarui dengan Undang-Undang Nomor 23 Tahun 2014 tentang Pemerintah Daerah, telah membawa implikasi yang luas berupa perubahan sistem pemerintahan daerah di Indonesia. Sebelum diberlakukannya undang-undang tersebut, sistem pemerintahan lebih bersifat sentralistik, sehingga setiap keputusan yang menyangkut kepentingan daerah lebih banyak ditetapkan oleh pemerintah pusat. Kondisi ini mengakibatkan daerah sering kehilangan inisiatif membangun, di samping dana yang dimiliki oleh pemerintah daerah yang juga sangat terbatas.

Otonomi daerah muncul karena adanya tuntutan pembagian kewenangan yang lebih besar untuk mengelola pemerintahan daerah dengan lebih baik.Otonomi daerah juga diharapkan dapat merangsang kemandirian dan kreativitas dalam mengembangkan wilayah masing-masing.Dengan diberikannya otonomi kepada daerah, berarti pemerintah pusat memberikan kewenangan kepada pemerintah daerah untuk mengatur rumah tangganya sendiri, termasuk dalam hal inisiatif membangun sarana publik, seperti pembangunan TPA sampah di wilayahnya masing-masing.

Adanya kewenangan untuk mengatur rumah tangga sendiri pada eraotonomi daerah ini, sebenarnyamembawa konsekuensi bahwa seharusnya pemerintah daerah tidak lagi mengandalkan bantuan keuangan dari pemerintah pusat dalam membiayai programprogram pembangunannya.Pemerintah daerah dituntut untuk berusaha semaksimal mungkin mengelola kemampuan, kemauan, dan sumberdaya yang dimilikinya.Daerah perlu menginventarisir sumber-sumber kekayaan dan menggali potensi sumber pendapatan yang dapat digunakan untuk membiayai pembangunan,tanpa harus membebani masyarakat.Hal ini perlu ditekankan, karena sesungguhnya tujuan dari pemberian wewenang yang luas kepada daerah dalam bentuk otonomi daerah, dimaksudkan untuk mempercepat peningkatan kesejahteraan masyarakatnya.

Dalam pembangunan dan pengembangan TPA, sangatlah penting memperhatikan masyarakat yang tinggal di sekitarnya, karena pengoperasian TPA akan memberikan dampak terhadap lingkungan sekitarnya ${ }^{(1)}$. Beberapa kasus TPA sering kali tidak memperhatikan masyarakat sekitar.Informasi hanya dilakukan satu arah serta keterlibatan masyarakat dalam organisasi pengelolaan TPA tidak ada.Masyarakat hanya mendapat keuntungan dari keberadaan TPA melalui warung yang mereka buka atau menjadi buruh bangunan dan pemulung.

Pemberian kewenangan melalui otonomi dimaknai sebagai upaya mendekatkan pelayanan pemerintah kepada masyarakat, dengan asumsi semakin dekat pemerintah pada rakyatnya, maka pemerintah akan semakin mengetahui kebutuhan rakyatnya. Di samping itu, semakin dekat pemerintah kepada rakyat, maka akan semakin cepat pelayanan yang diberikan. Akan tetapi, kemudian timbul persoalan ekonomi karena pemberian otonomi untuk mengatur rumah tangga sendiri ini, tidak disertai dengan kemampuan keuangan secara mandiri untuk membiayai berbagai program pembangunan daerah.Rendahnya kemampuan keuangan daerah dapat dilihat dari sisi pembiayaan pembangunan.Walaupun kerjasama regional telah diatur dalam perundangan, namun pelaksanaan dan konsekuensinya menjadi kewenangan masing-masing daerah, sehingga tidak ada prosedur yang standar sebagai acuan.Terlebih lagi Undang-Undang Otonomi Daerah memunculkan keegoan daerah yang tinggi, sehingga kurang mempertimbangkan efek terhadap daerah sekitarnya.Oleh karena itu, maka sangat diperlukan kerjasama regional yang benar-benar menjadi acuan bagi pelaksanaan pembangunan infrastruktur regional ${ }^{(1)}$.

Proses desentralisasi di Indonesia baru pada tahap desentralisasi dari sisi pengeluaran pemerintah dan belum sampai pada tahap desentralisasi dari sisi penerimaan, sehingga sebagian besar pemerintah daerah dalam membiayai pembangunannya, yang tercermin dalam besaran Anggaran Pendapatan dan Belanja Daerah (APBD), lebih mengandalkan subsidi dari pemerintah pusat, melalui dana perimbangan yang ditransfer dari pusat ke daerah dalam beberapa skema ${ }^{(2)}$. Selain hal tersebut masalah yang belum terpecahkan lainnya pada era otonomi daerah adalah masalah politik.Untuk mengatasi dua persoalan tersebut, baik masalah politik maupun ekonomi, agar pelaksanaan otonomi daerah mampu meningkatan kesejahteraan masyarakat, maka kegiatan kerjasama antardaerah dapat dijadikan solusi $^{(2)}$. 
Kerjasama antarpemerintah daerah di lapangan dalam pengembangan TPA regional belum berjalan seperti yang diharapkan. Kendala yang cukup menonjol antara lain: (a) Sulitnya membangun kesepakatan antarpemerintah daerah dalam kerjasama pengelolaan TPA Regional; (b) Adanya perbedaan orientasi dan kepentingan setiap pemerintah daerah dalam pengelolaan sampah; (c) Rumitnya pemilihan lokasi yang sesuai, persentasi pembebanan tipping fee terhadap setiap pemerintah daerah; (d) Sulitnya merumuskan model kerjasama pengelolaanTPA Sampah Regional.

Hasil penelitian ${ }^{(3)}$ mengenai TPA regional Bangli di Bali, untuk mendapatkan manfaat maksimal dan berkelanjutan dari dibangunnya TPA Regional Bangli perlu dilakukan kegiatan operasional dan pemeliharaan. Risiko dominan (major risk) yang dapat menghambat operasional dan pemeliharanTPA Regional Bangli adalah hambatan untuk membentuk lembaga yang bertanggung jawab secara penuh dalam operasional dan pemeliharaan TPA Regional, terbatasnya alokasi dana baik dari pemerintah pusat, pemerintah daerah provinsi, dan pemerintah daerah kabupaten yang terintegrasi dalam TPA Regional, hambatan melakukan kerjasama antara pemerintah dengan pihak swasta, dan risiko lainnya.

Pembangunan TPA regional masih merupakan hal yang baru dan manfaat jangka panjangnya masih belum terlihat ${ }^{(4)}$. Selain itu juga masih terdapat permasalahan kelembagaan, contohnya dalam kesepakatan antara beberapa pemerintah daerah, penentuan peran dan tanggung jawab, penghitungan kontribusi keuangan, dan akses yang berkesinambungan pada dana anggaran untuk pengoperasian dan pemeliharaan. Kesulitan dalam memperoleh lahan yang memadai masih tetap ada, begitu pula halnya dengan TPA regional. Namun kemajuan yang telah dicapai di wilayah seperti Mamminasata dan Kartamantul, serta rencana untuk membangun TPA regional tambahan, mengindikasikan bahwa model ini perlu diterapkan di Indonesia, tentunya dengan penyesuaian-penyesuaian yang memadai,sesuai dengan kondisi regional di berbagai wilayah di negara kita.

Apabila model kelembagaan TPA Regional ditemukan, tentu akan lebih memudahkan pemerintah daerah dalam mewujudkan sebuah TPA Regional yang dikelola secara efektif dan efisien, baik dari aspek kelembagaannya maupun operasionalnya. Penentuan model pengelolaan TPA regional ini tidak terlepas dari pemilihan wilayah yang akan bekerjasama dalam pengembangan TPA regional tersebut.Oleh karena itu maka perlu dilakukan analisis pemilihan wilayah terkait dengan TPA regional.

Tujuan dari penelitian ini adalah untuk mengidentifikasi dan menganalisis kondisi TPA eksisting di Wilayah Jabodetabek; memilih prioritas wilayah di sekitar TPST Bantargebang yang dapat bekerjasama dengan Pemprov DKI Jakarta dalam pengelolaan TPA regional di TPST Bantargebang, serta untuk menganalisis kemungkinan TPST Bantargebang untuk dikembangkan menjadi TPA Regional melalui progam intensifikasi dan ekstensifikasi.

\section{BAHAN DAN METODE}

Penelitian ini dilakukan dari April 2014 sampai September 2014 di TPST Bantargebang, Kecamatan Bantargebang, Kota Bekasi. Selain itu juga dilakukan pengamatan dan pengambilan data di TPA kabupaten dan kota yang berada tidak terlalu jauh dari TPST Bantar Gebang, yakni di TPA (Tempat Pengolahan Akhir) di Jabodetabek seperti TPA Sumurbatu Kota Bekasi, TPA Burangkeng Kabupaten Bekasi, TPA Cipayung Kota Depok, TPA Cipeucang Kota Tangerang Selatan, TPA Rawa Kucing Kota Tangerang, TPA Jatiwaringin Kabupaten Tangerang, dan Kota Bogor dan Kabupaten Bogor TPA Galuga dilakukan pada Februari 2015 - Juni 2015.

Data primer dan data sekunder yang dikumpulkan pada penelitian ini diantaranya adalah data yang langsung berkaitan dengan operasional pengelolaan sampah di TPST Bantargebang, Bekasi di antaranya rata-rata volume sampah masuk, karakteristik sampah di Bantargebang, luas lahan, teknis dan penerapan pengelolaan sampah di TPST Bantargebang, dan lain-lain serta dari TPA sekitarnya yakni TPA Sumurbatu Kota Bekasi, TPA Burangkeng Kabupaten Bekasi, TPA Cipayung Kota Depok, TPA Cipeucang Kota Tangerang Selatan, TPA Rawa Kucing Kota Tangerang, TPA Jatiwaringin Kabupaten Tangerang, dan Kota Bogor dan Kabupaten Bogor TPA Galuga.Selain data-data yang dibutuhkan mengenai berbagai hal terkait dengan TPA, juga dilakukan pengambilan data primer dengan bantuan kuesioner kepada para pakar yang menguasai masalah sampah di wilayah tersebut di atas,untuk kebutuhan metoda TOPSIS.Oleh karena itu maka penunjukan pakar yang diwawancara pada penelitian ini ditentukan secara purposive sampling.

Analisis data yang dilakukan pada penelitian terkaitdengan operasional TPST dan TPA dilakukan secara deskriptif, namun analisis untuk pengambilan keputusan multikriteria menggunakan metoda TOPSIS (Technique For Order Preference By Similarity To Ideal Solution). Langkah-langkah dalam metode TOPSIS adalah sebagai berikut $^{(5)}$ :

\section{Langkah 1:}

Normalisasi matriks keputusan. 
Membuat matriks $D$ yang mengacu pada $m$ alternatif yang akan dievaluasi berdasarkan kriteria, dalam hal ini elemen $\mathrm{x}_{\mathrm{ij}}$ menyatakan hasil perhitungan atau penilaian terhadap alternatif kei yang berdasarkan kriteria ke-j, didefinisikan sebagai berikut:

$$
D=\left[\begin{array}{cccc}
x_{11} & x_{12} & x_{13} \cdots & x_{1 n} \\
x_{21} & x_{22} & x_{23} \cdots & x_{2 n} \\
\vdots & \vdots & \vdots & \\
x_{m 1} & x_{m 2} & x_{m 3} \cdots & x_{m n}
\end{array}\right] \ldots(1)
$$

Setiap elemen pada matriks $D$ dinormalisasikan untuk mendapatkan matriks normalisasi $R$. Elemen rij hasil dari normalisasi decision matrix $R$ dengan metode Euclidean length of a vector adalah:

$$
\begin{aligned}
& r_{i j}=\frac{x_{i j}}{\sqrt{\sum_{i=1}^{m} x_{i j}^{2}}} \\
& \text { keterangan: } \\
& \begin{array}{ll}
\mathrm{i} & =1,2,3, \ldots, \mathrm{m} \\
\mathrm{j} & =1,2,3, \ldots, \mathrm{n} \\
\mathrm{r}_{\mathrm{ij}} & =\text { matriks ternormalisasi ke }-\mathrm{ij} \\
\mathrm{x}_{\mathrm{ij}} & =\text { matriks keputusan }
\end{array}
\end{aligned}
$$

\section{Langkah 2:}

Pembobotan pada matriks yang telah di normalisasi.

Dengan bobot $W=(w 1, w 2, \ldots . ., w n)$, maka normalisasi bobot matriks $V$ adalah:

$$
\begin{aligned}
& V=\left[\begin{array}{cccc}
w_{1} r_{11} & w_{2} r_{12} & w_{3} r_{13} \cdots & w_{n} r_{1 n} \\
w_{1} r_{21} & w_{2} r_{22} & w_{3} r_{23} \cdots & w_{n} r_{2 n} \\
\vdots & \vdots & \vdots & \\
w_{1} r_{m 1} & w_{2} r_{m 2} & w_{3} r_{m 3} \cdots & w_{n} r_{m n}
\end{array}\right] \\
& \boldsymbol{V}=\left[\begin{array}{cccc}
v_{11} & v_{12} & v_{13} \cdots & v_{1 n} \\
v_{21} & v_{22} & v_{23} \cdots & v_{2 n} \\
\vdots & \vdots & \vdots & \\
v_{m 1} & v_{m 2} & v_{m 3} \cdots & v_{m n}
\end{array}\right]
\end{aligned}
$$

Nilai $v$ dalam weighted normalized decision matrix diperoleh dari rumus sebagai berikut:

$$
v_{i j}=w_{i} r_{i j}
$$

$$
\text { keterangan : }
$$

$\mathrm{V}_{\mathrm{ij}}=$ matriks normalisasi terbobot $\mathrm{ke}-\mathrm{ij}$

$\mathrm{W}_{\mathrm{i}}=$ vektor bobot ke-j

$\mathrm{i}=1,2,3, \ldots, \mathrm{m}$

$\mathrm{j}=1,2,3, \ldots, \mathrm{n}$

$r_{i j}=$ matriks ternormalisasi $k e-i j$

\section{Langkah 3:}

Menentukan solusi ideal positif $\mathbf{A}(+)$ dan solusi ideal negatif $A(-)$, istilah yang dipakai yaitu menentukan poin ideal dan anti-ideal.

Solusi ideal positif dinotasikan $A^{+}$, sedangkan solusi ideal negatif dinotasikan $A^{-}$, dimana secara matematik $A^{+}$dan $A^{-}$, dijelaskan sebagai berikut :

$$
\begin{aligned}
& A^{+}=\left\{\left(\max V_{i j} \mid j \in J\right),\left(\min V_{i j} \mid j \in J^{\prime}\right), i=1,2,3, \ldots,\right. \\
& \mathrm{m}\}=\left\{\mathrm{V}_{1}^{+}, \mathrm{V}_{2}^{+}, \ldots, \mathrm{V}_{\mathrm{n}}^{+}\right\}
\end{aligned}
$$

dengan:

$\mathrm{J}=\{1,2, \ldots, \mathrm{n}$ dan $\mathrm{j}$ berhubungan dengan positif kriteria $\}$

$\mathrm{J}^{\prime}=\{1,2, \ldots, \mathrm{n}$ dan $\mathrm{j}$ berhubungan dengan negatif kriteria $\}$

$\mathrm{V}_{\mathrm{j}}^{+} \quad=$ solusi ideal positif ke-j

$\mathrm{V}_{\mathrm{j}}^{-} \quad=$ solusi ideal negatif $\mathrm{ke}-\mathrm{j}$

Sehingga $A^{+} \quad \operatorname{dan} A^{-}$adalah untuk mewakili alternatif yang paling disukai (most preferable) ke solusi ideal dan kurang disukai (least preferable) secara berurutan.

\section{Langkah 4:}

\section{Menghitung separation measure $\left(\mathrm{S}_{\mathrm{i}}{ }^{*}\right)$.}

Separation measure $\left(\mathrm{Si}^{*}\right)$ adalah pengukuran jarak (dalam pandangan Euclidean) dari suatu alternatif ke solusi ideal positif dan solusi ideal negatif ${ }^{(6)}$. Perhitungan matematisnya adalah sebagai berikut:

(a) Rumus pengukuran jarak dari suatu alternatif ke solusi ideal positif

$$
\begin{aligned}
S_{i}^{+} & =\sqrt{\sum_{j=1}^{n}\left(v_{i j}-A_{j}^{+}\right)^{2}}, \text { untuk } \mathrm{i}=1,2,3, \ldots, \mathrm{m} \quad . .(8) \\
& \text { keterangan: } \\
\mathrm{S}_{\mathrm{i}}^{+} & =\text {jarak alternatif } \mathrm{A}_{\mathrm{i}} \text { dengan solusi ideal positif } \\
\mathrm{V}_{\mathrm{ij}} & =\text { matriks normalisasi terbobot ke-ij } \\
\mathrm{V}_{\mathrm{j}}^{+} & =\text {solusi ideal positif ke- } \mathrm{j}
\end{aligned}
$$

(b) Rumus pengukuran jarak dari suatu alternatif ke solusi ideal negative

$$
\begin{aligned}
& S_{i}^{-}= \sqrt{\sum_{j=1}^{n}\left(v_{i j}-A_{j}^{-}\right)^{2}}, \text { untuk } \mathrm{i}=1,2,3, \ldots, \mathrm{m} \\
& \text { keterangan: } \\
& \mathrm{S}_{\mathrm{i}}^{-}=\text {. jarak alternatif } \mathrm{A}_{i} \text { dengan solusi ideal negatif } \\
& \mathrm{V}_{\mathrm{i}_{j}}=\text { matriks normalisasi terbobot ke-ij } \\
& \mathrm{V}_{\mathrm{j}}=\text { = solusi ideal negatif ke- } \mathrm{j}
\end{aligned}
$$

\section{Langkah 5:}

Menghitung kedekatan relatif dengan solusi ideal

Untuk menghitung kedekatan relatif $\left(\mathrm{C}_{\mathrm{i}}^{+}\right)$dari alternatif $A_{i}$ dengan solusi ideal positif $A^{+}$ direpresentasikan dengan:

$$
C_{i}^{+}=\frac{S_{i}^{-}}{S_{i}^{+}+S_{i}^{-}}
$$


keterangan :

$0<\mathrm{C}_{\mathrm{i}}^{+}<1$ dan $\mathrm{i}=1,2,3, \ldots, \mathrm{m}$

$\mathrm{C}_{\mathrm{i}}^{+}=$kedekatan tiap alternatif terhadap solusi ideal positif

$\mathrm{S}_{i}^{+}=$jarak alternatif $\mathrm{A}_{i}$ dengan solusi ideal positif

$S_{i}^{-}=$jarak alternatif $A_{i}$ dengan solusi ideal negatif

Dengan ketentuan bahwa alternatif $A_{i}$ dikatakan dekat dengan solusi ideal positif apabila $\mathrm{C}_{i}^{+}$ mendekati nilai 1. Jadi $C_{i}^{+}=1$, jika $A_{i}=A^{+}$dan $\mathrm{C}_{\mathrm{i}}^{-}=0$, jika $\mathrm{A}_{\mathrm{i}}=\mathrm{A}^{-}$.

\section{Langkah 6: \\ Mengurut prioritas alternatif}

Penentuan prioritas alternatif dilihat dari nilai $\mathrm{C}_{i}^{+}$ yang mendekati 1 atau alternatif terbaik merupakan salah satu yang berjarak terpendek terhadap solusi ideal dan berjarak terjauh dengan solusi negatif-ideal ${ }^{(7)}$.

\section{HASIL DAN PEMBAHASAN}

Di sekitar TPST Bantargebang, terdapat Kota Bekasi, Kabupaten Bekasi, Kota Depok, Kota Tangerang Selatan, Kota Tangerang, Kabupaten Tangerang, Kota Bogor, dan Kabupaten Bogor. Kedelapan wilayah ini selain merupakan penyangga langsung ibukota, sehingga terjadi interaksi penduduk antar ke delapan wilayah tersebut dengan ibukota yang sangat erat, termasuk dinamika timbulan dan mutasi sampah yang terjadi antarwilayah tersebut.Masingmasing wilayah tersebut memiliki TPA sendiri, tetapi sampai saat ini, TPA-TPA tersebut sudah dalam kondisi jenuh.Kondisi TPA-TPA tersebut saat ini malah sudah menjelang pada saat-saat tidak dapat lagi menerima sampah.

Kota Bekasi juga memiliki TPA Sumur Batu, Kabupaten Bekasi mempunyai TPA Burangkeng, Kota Depok mempunyai TPA Cipayung, Kota Tangerang Selatan memiliki TPA Cipeucang di Kecamatan Serpong, Kota Tangerang memiliki TPA Rawa Kucing di Kecamatan Neglasari, Kabupaten Tangerang memiliki TPA Jatiwaringin di Kecamatan Mauk, sedangkan Kota Bogor dan Kabupaten Bogor memiliki TPA Galuga. Kondisi masing-masing TPA ini seperti pada Tabel 1 berikut ini.

\subsection{Pemilihan Wilayah yang Terkait dengan TPARegional di TPST Bantargebang.}

Tempat Pengolahan Sampah Terpadu (TPST) Bantargebang, sudah menerima sampah sejak tahun 1989 dari lima wilayah yang ada di Jakarta. Pengelolaan sampah di TPST ini selain dilakukan secara swakelola oleh Dinas Kebersihan DKI Jakarta, pernah juga dikelola oleh pihak swasta yaitu PT. Patriot Bangkit Bekasi.Saat ini, pengelolaan fasilitas ini dilakukan oleh operasi bersama dua perusahaan swasta yaitu PT. Godang Tua Jaya dan PT. Navigat Organic Energy Indonesia.TPST ini menerima sampah dari Jakarta lebih dari 6,000 ton perhari.

Pengembangan TPA (Tempat Pemrosesan Akhir) sampah regional, merupakan satu hal yang perlu dilakukan sesegera mungkin dalam hal pengelolaan sampah di Indonesia.Mengingat dengan adanya pengembangan TPA (Tempat Pemrosesan Akhir) sampah regional ini, diharapkan pengelolaan sampah di Indonesia dapat dilakukan dengan lebih baik dan tersistem. Masalah-masalah yang dihadapi oleh para pemerintah daerah, seperti: keterbatasan anggaran yang tersedia untuk pengelolaan sampah, serta ketersediaan lahan yang cukup dan sesuai untuk pengembangan TPA, membuat kebutuhan pengembangan TPA sampah regional menjadi teramat penting. Dengan adanya model kelembagaan TPA sampah regional ini, diharapkan pemerintah daerah memiliki acuan dalam mengelola sampahnya, termasuk di dalamnya pengembangan TPST Bantargebang menjadi TPA regional. 
Tabel 1. Kondisi Eksisting TPST Bantargebang dan Delapan TPA di Sekitarnya

\begin{tabular}{|c|c|c|c|c|}
\hline $\begin{array}{l}\text { Nama } \\
\text { TPST/TPA }\end{array}$ & $\begin{array}{l}\text { Luas } \\
\text { (ha) }\end{array}$ & Mulai Operasi & Asal Sampah & Mekanisme kontrak \\
\hline $\begin{array}{l}\text { Bantar } \\
\text { Gebang }\end{array}$ & 120.8 & Agustus 1989 & $\begin{array}{lr}\text { Jakarta } & \text { Utara, } \\
\text { Jakarta } & \text { Timur, } \\
\text { Jakarta } & \text { Selatan, } \\
\text { Jakarta } & \text { Barat, dan } \\
\text { Jakarta } & \text { Pusat. }\end{array}$ & $\begin{array}{l}\text { Seluas } 10,5 \text { hektar merupakan milik pengelola } \\
\text { saat ini, yang akan diserahkan kepada } \\
\text { Pemerintah Provinsi Jakarta pada akhir kontrak, } \\
\text { yaitu pada tahun 2023, melalui mekanisme } \\
\text { kontrak BOT (Build-Operate-Transfered) atau } \\
\text { Bangun-Guna-Serah }\end{array}$ \\
\hline $\begin{array}{l}\text { Sumur } \\
\text { Bekasi }\end{array}$ & 14.2 & $\begin{array}{l}\text { Dinas } \\
\text { Kebersihan dan } \\
\text { Pertamanan }\end{array}$ & $\begin{array}{l}12 \text { Kecamatan di } \\
\text { Kota Bekasi. }\end{array}$ & $\begin{array}{l}\text { Tahun } 2003 \text { telah dipakai sistem controlled lanfill } \\
\text { untuk menekan pencemaran lingkungan. volume } \\
\text { timbulan sampah di Kota Bekasi mencapai } 1,500 \\
\text { ton/hari dan hanya } 500 \text { ton dari volume tersebut } \\
\text { yang dikirim ke TPA Sumur Batu,. Pemerintah } \\
\text { Kota Bekasi, tahun } 2015 \text { sudah mengirimkan } \\
\text { surat kepada Pemerintah Provinsi DKI Jakarta } \\
\text { untuk diperbolehkan mengirimkan sampahnya ke } \\
\text { TPST Bantargebang, }\end{array}$ \\
\hline $\begin{array}{l}\text { Burangkeng, } \\
\text { Bekasi }\end{array}$ & 11 & $\begin{array}{l}\text { Dinas } \\
\text { Kebersihan, } \\
\text { Pertamanan } \\
\text { dan Pemadam } \\
\text { Kebakaran. }\end{array}$ & 14 Kecamatan & $\begin{array}{l}\text { Pada tahun } 2013 \text { volume timbulan sampah warga } \\
\text { Kabupaten Bekasi yang tersebar di } 23 \text { kecamatan } \\
\text { mencapai } 6,750 \mathrm{~m}^{3} / \text { hari, namun hanya } \pm 18 \% \text { dari } \\
\text { total volume tersebut atau } 1,230 \mathrm{~m}^{3} \text { yang dapat } \\
\text { terangkut ke TPA Burangkeng dengan sistem } \\
\text { open dumping }\end{array}$ \\
\hline $\begin{array}{l}\text { Cipayung Kota } \\
\text { Depok }\end{array}$ & 11.6 & $\begin{array}{l}\text { Dinas } \\
\text { Kebersihan dan } \\
\text { Pertamanan } \\
\text { Kota Depok }\end{array}$ & $\begin{array}{l}\text { 1/3 dari luas daerah } \\
\text { Kota Depok. }\end{array}$ & $\begin{array}{l}\text { Beroperasi sejak tahun } 1984, \\
\text { menggunakan sistem controlled landfill }\end{array}$ \\
\hline $\begin{array}{l}\text { Cipaucang, } \\
\text { Kota Tangsel }\end{array}$ & 6.8 & $\begin{array}{l}\text { Dinas } \\
\text { Kebersihan } \\
\text { Pertamanan } \\
\text { dan } \\
\text { Pemakaman }\end{array}$ & Kota Tangsel & $\begin{array}{l}\text { tingkat kelayakan TPA Cipeucang terendah } \\
\text { dibandingkan TPA Rawa Kucing (Kota } \\
\text { Tangerang) dan TPA Jatiwaringin (Kabupaten } \\
\text { Tangerang). Selanjutnya dikatakan bahwa TPA } \\
\text { Cipeucang akan memenuhi syarat sebagai TPA } \\
\text { namun harus dilakukan perbaikan yang cukup } \\
\text { berat, sehingga perlu perbaikan pada aspek } \\
\text { manajemen, persepsi masyarakat, dan fisik. }\end{array}$ \\
\hline $\begin{array}{l}\text { Rawa Kucing } \\
\text { Tangsel }\end{array}$ & 34.8 & $\begin{array}{l}\text { Dinas } \\
\text { Pekerjaan } \\
\text { Umum Kota } \\
\text { Tangerang }\end{array}$ & $\begin{array}{l}13 \text { Kecamatan di } \\
\text { Kota Tangsel }\end{array}$ & $\begin{array}{l}\text { TPA Rawa Kucing diprediksi akan jenuh pada } \\
\text { tahun } 2016 \text {. Pemerintah daerah setempat sudah } \\
\text { bersiap menyediakan lahan cadangan TPA di } \\
\text { Jatiwaringin, Kabupaten Tangerang. }\end{array}$ \\
\hline $\begin{array}{l}\text { Jatiwaringin, } \\
\text { Kab } \\
\text { Tangerang }\end{array}$ & 12 & $\begin{array}{l}\text { Dinas } \\
\text { Kebersihan } \\
\text { Pertamanan } \\
\text { dan } \\
\text { Pemakaman } \\
\text { (DKPP }\end{array}$ & $\begin{array}{l}\text { Kabupaten } \\
\text { Tangerang }\end{array}$ & $\begin{array}{l}\text { beroperasi sejak tahun } 1992 \text { untuk menampung } \\
\text { sampah saja, tetapi tahun } 2011 \text { fasilitas diubah } \\
\text { menjadi tempat pengelolaan sampah. } \\
\text { Cakupan pelayanan sampah di Kabupaten } \\
\text { Tangerang sebesar } 27 \% \text { terlayani oleh DKPP, } 7 \% \\
\text { terlayani oleh swasta dan sisanya } 66 \% \text { belum } \\
\text { terlayani }\end{array}$ \\
\hline $\begin{array}{l}\text { Galuga Kab } \\
\text { Bogor }\end{array}$ & 31.8 & $\begin{array}{l}\text { Dinas } \\
\text { Kebersihan } \\
\text { Pertamanan }\end{array}$ & Kota dan Kab Bogor & $\begin{array}{l}\text { TPA Galuga menyebabkan air sumur sekitar } \\
\text { wilayah Galuga tidak layak untuk air baku air } \\
\text { minum peruntukkan air Kelas I. Parameter } \\
\text { kualitas air yang melampaui ambang batas } \\
\text { maksimum yaitu bau (busuk), rasa (agak asam, } \\
\text { dan agak pahit), pH, oksigen terlarut (DO), } \\
\text { kebutuhan oksigen biokimiawi (BOD), kebutuhan } \\
\text { oksigen kimiawi (COD), amonia, nitrit, seng (Zn), } \\
\text { bakteri fecal coli dan coliform. } \\
\text { Pada tahun } 2014 \text { volume timbulan sampah Kota } \\
\text { Bogor mencapai } 2,484 \mathrm{~m}^{3} / \text { hari, namun yang } \\
\text { terangkut ke TPA Galuga hanya } 1,748 \mathrm{~m}^{3} / \text { hari. }\end{array}$ \\
\hline
\end{tabular}




\subsection{Analisis Pemilihan Wilayah untuk TPA Regional di TPST Bantargebang}

Penentuan alternatif prioritas dalam pemilihan wilayah mana saja yang akan menggunakan TPST Bantargebang sebagai TPA Regional, didasarkan pada beberapa kriteria. Kriteria yang digunakan diperoleh melalui kajian pustaka dan mendapatkan informasi melalui kuesioner TOPSIS dengan para ahli/ pakar sampah. Kriteria yang diperlukan dalam penentuan alternatif yang paling prioritas untuk penentuan wilayah rekomendasi ini ada enam, yang terdiri dari (1) jarak dari wilayah sumber sampah ke TPST Bantargebang, (2) besarnya biaya yang diperlukan untuk mengangkut sampah ke TPST Bantargebang, (3) akses dari wilayah sumber sampah ke TPST Bantargebang, (4) hubungan birokrasi antarwilayah sumber sampah dengan Pemprov DKI Jakarta, (5) kemampuan wilayah untuk membayar tippingfee, kepemilikan lahan yang sesuai untuk TPST. Untuk alternatif prioritas rekomendasi yang akan dipilih ada delapan alternatif prioritas wilayah, yaitu: Kota Bekasi, Kabupaten Bekasi, Kota Depok, Kota Bogor, Kabupaten Bogor, Kota Tangerang Selatan, Kabupaten Tangerang, dan Kota Tangerang.

Tabel 2. Matrik Keputusan dan Bobot Masingmasing Kriteria

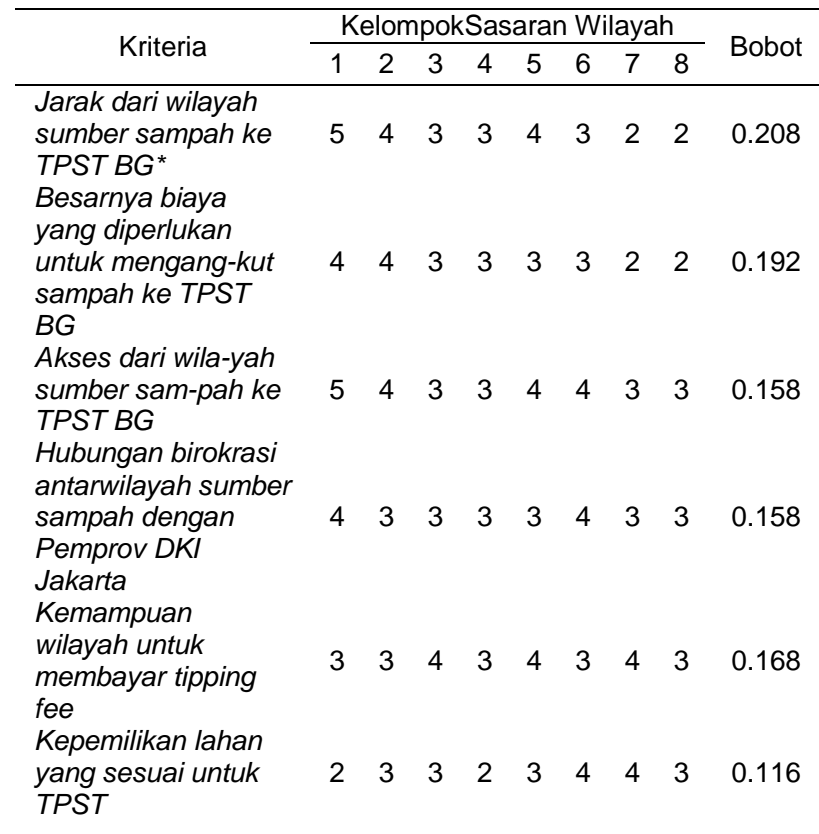

Keterangan:

1. Kota Bekasi, 2. Kab.Bekasi, 3.Kota Depok, 4.Kota Bogor,

5.Kab.Bogor, 6. Kota Tangerang Selatan, 7. Kab., Tangerang, 8. Kota Tangerang

Dalam kasus pemilihan alternatif prioritas dalam pemilihan daerah mana saja yang ada di sekitar Bantargebang yang akan menggunakan TPST Bantargebang, menggunakan 6 kriteria dengan 8 alternatif. Skala nilai yang digunakan dari 1 sampai 7.Dalam hal ini 1 (sangat tidak penting) adalah nilai yang paling rendah dan 7 (sangat penting) adalah nilai yang sangat tinggi. Dengan metode TOPSIS diperoleh alternatif yang berjarak terpendek terhadap solusi ideal dan berjarak terjauh dengan solusi negatif-ideal yaitu wilayah yang terpilih untuk menggunakan TPST Bantargebang sebagai TPA Regional.

Hasil penelitian menunjukkan, bahwa responden lebih memilih kriteria jarak dari sumber wilayah sumber sampah ke TPST Bantargebang, sebagai kriteria dengan bobot yang paling besar (Tabel 2). Kriteria jarak tersebut akan berkorelasi positif dengan kriteria besarnya biaya pengangkutan sampah ke TPST Bantargebang.

Dalam pemilihan alternatif yang paling prioritas dalam pemilihan wilayah yang ada di sekitar TPST Bantargebang, yang akan menggunakan TPST Bantargebang sebagai TPA Regional ini, diperoleh bahwa Kota Bekasi merupakan alternatif terbaik, nilai $\mathrm{Ci}_{+}$yang paling mendekati angka 1 . Hal ini juga berarti bahwa alternatif Kota Bekasi berjarak terpendek terhadap solusi ideal dan berjarak terjauh dengan solusi negatif-ideal.Hasil analisis TOPSIS juga mendapatkan alternatif terbaik kedua yakni Kabupaten Bekasi, sedangkan alternatif terbaik ketiga adalah Kabupaten Bogor (Tabel 3).

Tabel 3. Nilai $\mathrm{C}_{i}^{+}$untukAlternatif Wilayah yang Akan Dipilih

\begin{tabular}{|c|l|c|}
\hline No & \multicolumn{1}{|c|}{ Alternatif Wilayah } & \multicolumn{1}{c|}{} \\
\hline 1 & Kota Bekasi & 0.960 \\
\hline 2 & Kabupaten Bekasi & 0.742 \\
\hline 3 & Kota Depok & 0.277 \\
\hline 4 & Kota Bogor & 0.198 \\
\hline 5 & Kabupaten Bogor & 0.651 \\
\hline 6 & Kota Tangerang Selatan & 0.377 \\
\hline 7 & Kabupaten Tangerang & 0.111 \\
\hline 8 & Kota Tangerang & 0.022 \\
\hline
\end{tabular}

Melihat kondisi TPA Sumur Batu Kota Bekasi dan TPA Burangkeng Kabupaten Bekasi, sangatlah tepat apabila(sesuai dengan hasil analisis TOPSIS ini), kedua wilayah ini bekerjasama dengan Pemerintah Provinsi Jakarta dalam hal pengelolaan sampahnya di TPST Bantargebang. Kriteria jarak dari wilayah sumber sampah yaitu Kota dan Kabupaten Bekasi ke TPST Bantargebang, mendapatkan bobot paling besar dan diikuti dengan kriteria besarnya biaya yang diperlukan untuk mengangkut sampah ke TPST Bantargebang (Tabel 3).

Ketiga wilayah ini, yaitu Kota Bekasi, Kabupaten Bekasi dan Kabupaten Bogor, merupakan wilayah yang memiliki jarak terpendek ke TPST Bantargebang, sehingga wilayah-wilayah ini akan mengeluarkan biaya pengangkutan 
sampah yang lebih kecil dibandingkan dengan lima wilayah lainnya. Kabupaten Bogor sendiri memiliki jarak terpendek ke TPST Bantargebang, terutama wilayah timur Kabupaten Bogor, seperti Kecamatan Gunung Putri, Kecamatan Cileungsi, Kecamatan Klapa Nunggal dan Kecamatan Jonggol. Tempat Pemrosesan Akhir (TPA) sampah untuk ketiga wilayah ini sendiri, sampai saat ini sudah mencapai titik jenuh, baik TPA Sumur Batu milik Kota Bekasi, TPA Burangkeng Kabupaten Bekasi dan TPA Galuga Kabupaten Bogor. Tentunya TPA Regional Bantargebang akan menjadi solusi tepat bagi ketiga wilayah ini untuk menyelesaikan permasalahan hilir pengelolaan sampahnya.

TPA Regional Nambo, yang ada di Kabupaten Bogor, dalam rencana pengembangannya hanya akan melibatkan tiga wilayah, yaitu: Kota Bogor, Kabupaten Bogor dan Kota Depok ${ }^{(8)}$. Dengan demikian, Kota dan Kabupaten Bekasi tidak termasuk dalam kerjasama TPA Regional Nambo, sehingga sangat tepat apabila bersama Pemerintah Provinsi Jakarta membentuk kerjasama dalam pengelolaan TPA Regional di TPST Bantargebang.

\section{Kesiapan} operasional TPST Bantargebang untuk menjadi TPA regional perlu dilakukan analisis situasional deskriptif. Luas lahan TPST Bantargebang saat ini sebesar 120.8 hektar, tentunya akan memiliki daya tampung yang terbatas, dengan melihat pada volume sampah yang akan diterima. Tahun 2015, sampah dari lima wilayah Jakarta yang dikirim ke TPST Bantargebang saja sudah sebesar 6169.83 ton perhari. Pada tahun 2014 dengan jumlah penduduk mencapai 2.5 juta jiwa, volume timbulan sampah di Kota Bekasi mencapai 1,500 ton/hari atau $6000 \mathrm{~m}^{3} /$ hari, dan hanya 500 ton dari volume tersebut yang dikirim ke TPA Sumur Batu. Pada tahun 2013 volume timbulan sampah warga Kabupaten Bekasi yang tersebar di 23 kecamatan mencapai $6.750 \mathrm{~m}^{3} /$ hari, namun hanya sekitar $18 \%$ dari total volume tersebut atau $1.230 \mathrm{~m}^{3}$ atau lebih kurang sebesar 275 ton perhari yang dapat terangkut ke TPA Burangkeng. Volume sampah Kabupaten Bogor, tahun 2015 yang terangkut ke TPS Galuga mencapai 450 ton/hari. Dengan asumsi volume sampah Kabupaten Bogor yang dikirim ke TPST Bantargebang sebesar 50\%, maka total volume sampah yang akan dikir ke TPS Bantargebang dari keempat wilayah tersebut adalah sebesar 7,169 ton perhari.

Jumlah sampah ini dapat diterima oleh TPST Bantargebang, bila program intensifikasi dan ekstensifikasi dilakukan.Program intensifikasi dimaksud adalah, program yang dijalankan dengan menggunakan teknologi yang dapat mereduksi sampah, seperti pengomposan untuk sampah organik, daur ulang sampah plastik, dan teknologi pengolahan sampah menjadi energi listrik (waste to energy).Program ekstensifikasi adalah program yang dijalankan berupa perluasan lahan TPST Bantargebang eksisting, dengan lahan baru di sekitar lahan yang sudah ada.

Hasil pengumpulan data di lapang, menunjukkan perluasan lahan TPST ini dapat dilakukan sampai luas 25 - 30 hektar, yang merupakan lahan milik pengelola saat ini. Program ekstensifikasi seluas 25 hektar, dengan ketinggian efektif sampah di landfill 30 meter, ketinggian trap sampah 3 meter, faktor konversi 1 ton sampah adalah 3 meter $^{3}$, faktor pemadatan 50 persen serta faktor penyusutan alamiah 3 persen, maka diperoleh bahwa TPST Bantargebang masih dapat menerima sampah sebesar 2,422 ton per hari selama 15 tahun ke depan.

Kombinasi program ekstensifikasi dan intensifikasi ini membuat TPST Bantargebang memungkinkan untuk dijadikan TPA regional untuk keempat wilayah tersebut.

\section{KESIMPULAN DAN SARAN}

Kondisi TPA eksisting di Wilayah Jabodetabek sudah jenuh dan tidak dimungkinkan lagi untuk dikembangkan, Dalam pemilihan alternatif yang prioritas dalam pemilihan wilayah yang ada di sekitar TPST Bantargebang, yang akan menggunakan wilayah ini sebagai TPA Regional ini, diperoleh bahwa Kota Bekasi merupakan alternatif terbaik, selanjutnya adalah Kabupaten Bekasi dan Kabupaten Bogor.

TPST Bantargebang memungkinkan untuk dikembangkan menjadi TPA Regional dengan melakukan progam intensifikasi dan program ekstensifikasi.namun perlu diakukan kajian atau penelitian lanjutan mengenai model kelembagaannya.

\section{DAFTAR PUSTAKA}

1. Wyndiawaty, R., (2000), Prosedur Kerjasama Regional dalam Pembangunan dan Pengelolaan Infrastruktur. Jurnal PWK Vol. 11 No. 3/September 2000: 125-132.

2. Brodjonegoro, (2008), Otonomi Daerah dan Disentralisasi Ekonomi. FEUI, Jakarta.

3. Yasa,I.W., Dharma, I.G.B., \& Sudipta, I.G.K., (2013), Manajemen Risiko Operasional Dan Pemeliharaan Tempat Pembuangan Akhir (Tpa) Regional Bangli di Kabupaten Bangli. Jurnal Spektran Bol 1 No.2: 30-38.

4. Friedman, J., (2013), Memperkuat Lingkungan Kelembagaan untuk Manajemen Persampahan Perkotaan. Jurnal Prakarsa Infrastruktur IndonesiaEdisi 15/Oktober 2013: 13-18.

5. Hwang,C.L.\& Yoon,K., (1981), Multiple Attribute Decision Making: Methods and Applications. Springer Verlag: Berlin. 
6. Banwet D. K and Majumdar. A., (2014), "Comparative analysis of AHP-TOPSIS and GA-TOPSIS methods for selection of raw materials in textile industries," pp. 2071-2080,

7. Sarraf et al., (2013), Landscape of the PARKIN-dependent ubiquitylome in response to mitochondrial depolarization. Nature. 2013
Apr 18;496(7445):372-6. doi: 10.1038/nature12043. Epub 2013 Mar 17.

8. Unisystem U PT, Asia IRM. Pty. Ltd. Solid Waste Management for DKI Jakarta., (2005), Master Plan Review and Program Development II - 5. WJEMP Loan 4612INO/Credit 3519-IND (DKI 3-11). Jakarta (ID): Laporan WJEMP. 